\title{
Interdisciplinary approach to studying written nomadic sources in the context of modern historiology
}

\author{
Akmaral Ibrayeva ${ }^{1 *}\left(\mathbb{D}\right.$, Assemgul Temirkhanova ${ }^{2}$, Zaure Kartova', Tlegen Sadykov², Nurbolat Abuov ${ }^{1}$ and \\ Anatoliy Pleshakov ${ }^{1}$
}

\begin{abstract}
This article uses an interdisciplinary approach to analyze textual sources from nomadic civilization. Linguistic analysis has been increasingly used due to the emergence of a huge array of autochthonous and authentic written sources. It is impossible to extract the necessary historical information from those sources without using a new research method. This study aims to apply discourse analysis to medieval textual sources called edicts published in 1400-1635 by the leaders of the Central Asian states. This approach is expected to enable a detailed study of the structure of edicts, as well as speech patterns and terms used in the text. The results of the study revealed the structure of the examined edicts, as well as socio-cultural, economic, and communicative features of the nomadic society. First, the discourse repertoire of Edicts from Sygnak is rather unique, as evidenced by comparative analysis of patents from the cities of Sygnak, Sayram and Turkestan located in the Syr Darya basin. Second, edicts in this study reflect the result of the mutual influence of sedentary and mobile lifeways. Third, the arguments behind certain speech patterns used in the examined edicts emerged under the influence of Turkic traditions.
\end{abstract}

Keywords: Discourse analysis, Document structure, Edicts, Nomadic civilization, Oral historiology

\section{Introduction}

One of the major challenges of nomadic research is the insufficient number of textual sources, which hinders historical criticism. There are two possible solutions to this problem. Scholars can either improve their research approach or intensify efforts in the study of autochthonous texts. In the past, the Nomads developed a system of edicts, a formal written command from the ruler, which historians can now address in their research. The inscriptions, issued by local authorities, were determined by the ethnic ways of life. Thus, they varied between the ethnic groups. By their nature, these edicts were the

\footnotetext{
*Correspondence: akmibraeva@rambler.ru

1 Department of History of Kazakhstan and Socio-Humanitarian Disciplines, M. Kozybaev North Kazakhstan University, Pushkin Street, 86, Petropavlovsk 1500000, Kazakhstan

Full list of author information is available at the end of the article
}

documents with the content and legal form characteristic to contracts. Consequently, having a legal force, they differed from other documents of that time and thus constituted a separate type of sources. Edicts were issued to grant a person with special privileges: provide with land, exempt from taxes, appoint to positions, as well as offer other social and legal benefits. The right to issue edicts belonged to the authorities; however, given that their frequent replacement was the norm, the practice of edicts' reconfirmation was also quite a usual matter. Initially, nomadic research was focused on the ancient Turkic rune stones, ancient Turkic literature, and genealogical records, also known as the shezhire. The edicts, however, are more suitable for determining historical timeline and reasons behind certain events than the above sources, yet these autochthonous and authentic texts are poorly studied. It is difficult to overestimate the importance of edicts as primary sources of facts about the studied era

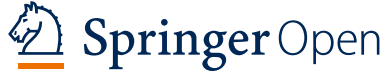

(c) The Author(s) 2021. Open Access This article is licensed under a Creative Commons Attribution 4.0 International License, which permits use, sharing, adaptation, distribution and reproduction in any medium or format, as long as you give appropriate credit to the original author(s) and the source, provide a link to the Creative Commons licence, and indicate if changes were made. The images or other third party material in this article are included in the article's Creative Commons licence, unless indicated otherwise in a credit line to the material. If material is not included in the article's Creative Commons licence and your intended use is not permitted by statutory regulation or exceeds the permitted use, you will need to obtain permission directly from the copyright holder. To view a copy of this licence, visit http://creativecommons.org/licenses/by/4.0/. The Creative Commons Public Domain Dedication waiver (http://creativeco mmons.org/publicdomain/zero/1.0/) applies to the data made available in this article, unless otherwise stated in a credit line to the data. 
and information about certain events that took place at the time. Today, edicts rarely became the focus of historical research.

The present paper attempts to apply discourse analysis to the Khan's edicts issued by Central Asian rulers to the cities of Sygnak, Sayram and Turkestan in the period from 1400 to 1635 . The research subject is represented precisely by the edicts of the Golden Horde (yarlyks) written according to specific canons [1].

Research historiography. The problem of edict translation into Kazakh language was addressed in a large number of previous studies. Ibatov [1], who explored the written culture and clerical traditions of the Golden Horde, contributed eight translations, among them diplomatic texts or bitiks, edicts, and texts of several seals. Turkish scientist A.N. Kurat was fruitfully engaged in act research. He studied edicts and bitiks that Turkish khans received from the Khans of the Golden Horde and the Crimea. These documents are now maintained in the Topkapı Palace Museum [2]. A significant portion of edict translations was from A. M. Özyetgin [3], who focused on edicts of the Golden Horde, Crimean and Kazan khanates.

Scientists from Tatarstan, Russia, and Uzbekistan were much more successful in exploring the world of edicts. Aksanov [4], for example, provided comprehensive insights into the patents of privileges of the Juchi Ulus, later known as the Golden Horde, dated back to the XIV-XVI centuries. After many years of research that he spent in archives, manuscript repositories and museums in Moscow, St. Petersburg, Kazan, Kyiv, Odessa, and Simferopol, he found a huge array of edicts. The author analyzed 61 authentic nobility patents in Turkic language and introduced 53 references for other researchers to examine. Grigoryev [5] presented the structure analysis of edicts from Mongolia, China, Central Asia and Iran, which survived till now. These documents date back to the XIII-XV centuries and are written in Mongolian, Chinese, Turkic, Persian and Arabic languages. Pochukayev is a researcher notable for applying novel approaches to the study of edicts. He saw edicts enclosing the law of the Golden Horde. Comparing edicts with similar legislative acts of other nations, such as institutions and proclamations of Roman emperors and capitularies, decrees, and bulls of European monarchs, the author distinguished certain trends in the national and legal development of the Golden Horde [6]. A group of scholars, who examined a significant amount of historical sources from the Mausoleum of Khawaja Ahmed Yasawi in Turkestan, put on scientific display documents that are now stored in private and state collections in Almaty, Turkestan, Tashkent and St. Petersburg. These pieces of legislative writings are devoted exclusively to the Mausoleum [7].
The historical research often makes use of the methods of multiple disciplines, such as paleography, diplomacy, sphragistics, and archeography. As scholars are currently shifting their attention to the quantitative and qualitative analyses of historical sources, the interdisciplinary approach is becoming more popular than ever. Given the effort to discover new types of historical sources, there is a need to find appropriate methods for their analysis and interpretation. One of the most popular interdisciplinary fields of inquiry is discourse analysis.

In modern historiology, a discursive approach previously described by Hayden White is becoming increasingly popular. Hayden White sought to conceptualize the linguistic dimension of historical writing. For this, he drew his attention to fixed speech patterns and stylistic nuances. According to him, an object of research gradually becomes a subject of discourse [8]. Consequently, speech patterns found in similar texts can be an object of discourse analysis. Trubina notes that the adjective "poetic" used by Hayden White to describe the nature of historian's work should be understood through the prism of the word "poiesis", which means the process of making, production, and creation [9]. In White's view, there is an element of poetry in every historical unit out there, and his Metahistory presents the analysis of rhetorical and narrative structures of historical writing [9].

Michel Foucault [10] defines discourse analysis as a method of investigation through which various discursive formations can be explored, such as notions, objects, strategies, etc. This technique can help researchers identify a connectedness between historical sources based on specific characters found within texts and trace the change of those characters over time. The founder of this research field, Émile Benveniste, drew a line between language and speech (discourse) [11], which enables identification of patterns of connectedness between phrases found within the same discourse. The presence of the same speech patterns, borrowed words, and expressions in historical text indicates the existence of certain events or public institutions that lead to their appearance. In this connection, changes over time in the structure of the edict should be considered systematically.

The past decade saw a growing interest in discourse investigation among researchers in various humanities and social science disciplines, such as sociology, history, ethnography, literary criticism, and philosophy, along with linguistics. There is no specific school to deal with the methodology of discourse analysis, but there are a number of studies devoted to discourse investigation methods. One of such works is Discourse Analysis as Theory and Method by Louise Phillips and Marianne Jørgensen. It brings together all interesting and useful 
information from a broad range of disciplines, such as linguistics, sociology, psychology, and more [12].

The discourse method was mostly used in philological and linguistic research. At the same time, the nomadic research has always been dominated by linguistic studies, and Turkology as a science began with the study of written sources. The increasing popularity of discourse analysis stems from the fact that most historical sources about the nomads extant are oral. The oral tradition of nomadic civilization has its grounds in psychological and socio-cultural factors [13]. The oral data aside, scholars focused on textual sources can determine if the historical text is reliable by looking at two variables: the time the source has been around, and the presence of new speech patterns in the primary structure of the text. From this perspective, the use of interdisciplinary solutions is rather reasonable.

The purpose of this work is to examine Edicts from Sygnak using the discourse method. In Turkology and medieval studies, there are many types of edicts, including mulk-nameh (charters of privilege), shert edicts (loyalty statements), waqf-nameh (charters on endowment), tarkhan grants (documents granting judicial and tax immunity), bitiks (diplomatic letters), and so on. However, there are differences in the use of speech units within edicts and in the structure of edicts themselves. This work focuses on comparing speech units in edict texts of the Middle Ages with the help of discourse analysis.

\section{Methods}

The research process comprises the following stages:

1. Selecting the literature through the exploration of historiographic materials and discourses on history, and examining the methods of historians in studying medieval written sources. Defining the range of methods for written sources analysis and historiographical review enables the next stage of research.

2. Analyzing the array of historical sources selected in stage one, which were not studied previously. This stage lays groundwork for making unique findings. The content analysis of edicts not only revealed the distinctive features of those written sources, but also showed how important they were in the context of historiology.

3. Synthesizing the entire range of historical sources available to authors with the view of discussing their scientific novelty and reliability. This stage ends with the display of research results.

4. Reaching conclusions.
As the number of written artefacts expands, it becomes evident that some categories of textual sources are exclusive and require other approaches to studying them, including the interdisciplinary method. Current developments in diplomacy, sphragistics, and textology pose new research challenges. One of them is the reconstruction of the structure of the written document in order to determine whether documents belong together, that is, to link a given document to a specific category of documents.

Sylvia Bendel Larcher [14] sees discourse as a social process of understanding how to interpret and shape the world. From this perspective, the discourse not only captures historical events, but also allows building a timeline of those events. This allows tracing changes that took place in society throughout history. Larcher [14] distinguishes six dimensions of discourse analysis, namely theme (thema), geographical location (geografischerraum), time period (zeitpanne), text medium (medium), participants (akteure), and the type of text (textsorte). Let us have a closer look at these dimensions.

The object of discourse analysis in this study is a corpus of edicts that have a socio-economic orientation. Thematic unity of discursive texts determines their semantic and stylistic homogeneity. Edicts under study cover a broad range of land-related and social issues, such as land tax immunity. It can be argued that there was an established procedure for preparing and issuing edicts, which was normalized by public institutions. The hierarchy of edicts comprises land ownership documents, documents for tax exemption, and documents providing privileges and benefits. The Tarkhan grants, for example, imply nine privileges that were granted to a tarkhan or military contingent commander. These topics correspond to different thematic levels of the discourse.

In regards to geographical distribution, the discourse develops and all changes are put on paper. After the collapse of the Golden Horde, edicts were the major type of regulatory acts among khanates. This entailed the widespread use of edicts in the XV-XVI centuries. At this point, the structure of edicts underwent minor changes, namely the new versions of sections, such as inscriptio (where addresses of the person to whom the document was issued for appeared), dispositio (where a decision that has been made is detailed), and sanctio (confirming of the dispositio or a warning), were introduced. The procedure of issuing edicts, however, remain as it was. Furthermore, edicts became known as part of official business documentation, and new types of edicts have been developed.

It is obvious that texts or discourses and discourse structures within these texts must have appeared at some point in history. First they have been run within nomadic societies and military democracies, and then become 
part of sedentary societies that adapted official texts in a certain way.

In the XIII through XVI centuries, edicts were produced by a narrow circle of people called scriveners (bitikchi), who were trained to write legal documents. The term "bitikchi" has a Uighur origin and means "a clerk". There were also translators called kelemechi [15]. Undoubtedly, bitikchi and kelemechi both has a high social status. Scriveners could influence the text of the edict, but did not change its structure and content.

Participants in the discourse are addressees and addressers belonging to different administrative ranks or without distinction of one. Hence, edicts can enclose information about the approximate number and composition of discourse participants, their social class, demographic, experiential or attitudinal backgrounds. These insights can help expand our knowledge of the institute of tarkhanism integral to nomadic society. Additional information that can be extracted from edicts can shed light on issues surrounding social mobility, status roles, and status-driven relationships.

Let us consider the following pieces of writing as an example. One of the earliest edicts by Mengu-Timur, the first khan of the Golden Horde, written in 1267 begins with the following words:

"By the power of the eternal God, Mengu-Timur hereby orders darugi [civilian governors], princes of cities and villages, princes of the army, scriveners, customs officers, traveling ambassadors, falconers, and hunters..." [6].

The edict of 1398 by Timur-Kutlug, however, addresses people with other titles, as evident by the following phrase:

"...orders oglans of right and left wings... captains over thousands, captains over hundreds, captains over tens, qadis [Islamic judges], muftis [legal experts], sheikhs [heads of religious orders], sufis, scriveners of the Chamber, tribute collectors, customs officers, road workers, bukauls [quartermasters], tutkauls [heads of the outposts], coachmen, market supervisors..." [16].

Edicts under study cover an even broader range of addressees. The Edict of $1634 / 1635$ by Abu-l-Ghazi Ubaydallah-Khan-Bahadur-Sultan, for example, reaches out to "...sayyids, great religious scholars, valiant scholars, high-ranking emirs, venerable qazis, sheikhs and sages", as well as "noble arbabs, the great (and) small kedhuda [paterfamilias], and raiyyats [farmers]", namely khodjas (small independent landowners) and shariks (farmers who rent land from large landowners) [16]. The appearance of members of the Muslim clergy (qadis, sheikhs, muftis) in later edicts indicates the adoption of Islam and the integration of Muslim institutions into the legal system of the Golden Horde [17, 18].

Besides clergy, the important members of medieval society were representatives of military-feudal nobility and civil administration, such as yuzbegi (captains over hundreds) and minbegi (captains over thousands), rulers of the districts and regions, and tax collectors. The Edict of 1597-1598 by Abu-l-Ghazi Abdallah-Khan-BahadurSultan is devoted to "venerable emirs, great arbabs, minbegi, yuzbegi, mirkhazars, raiyyats, [native] community, and all residents [living in the area]..." [16]. All of them were granted significant plots of land or received support at the expense of taxpayers. In the Edict of 1598, a number of drinking springs and several irrigation channels are called the "mulks of Sygnak residents" [16].

Specific types of texts define the boundaries of discourse. In written speech, discourse developed across the most important areas of socio-economic activity. This helps to reveal how public perceptions of the forms of ownership and the structure of social institutions changed over time. This also enables the use of sociological tools in historical research [19].

\section{Results}

This section presents the results of heuristic search, namely a list of previously unstudied textual sources, as well as the results of comparative structural analysis applied to edicts of the XIV-XVI centuries. A classification of the existing edicts was proposed, which is based on a novel methodological approach. Finally, the section reports on the results of discourse analysis.

The list of previously unstudied textual sources comprises documents known as Edicts from Sygnak, which include the following patents from the cities of Sygnak, Sayram and Turkestan located in the Syr Darya basin:

1. Patent of 1400/1401 from Timur Amir-by this document, Amir Timur appoints Siraj al-Din Shaykh as shaykh al-Islam in Sygnak and grants him tarkhanate, i.e., exemption from taxes. Copy, written in the Turkic language;

2. Patent of 1543/1544 from Abu'l-Ghazi Abd arRahim-Khan-Bahadur-Sultan-according to this document, Sirat-Shaykh-nakib was appointed as a judge of Sygnak. Original version, written in the Turkic language;

3. Patent of $1597 / 1598$ from Abu'l-Ghazi AbdallahKhan-Bahadur-Sultan-according to this document, Shaybanid Abdallah-Khan II gave a number of irrigation canals to the residents of Sygnak (at the request of Maulana Kamal al-Din). Original version, written in the Persian language; 
4. Patent of 1634/1635 from Abu'l-Ghazi UbaydallahKhan-Bahadur-Sultan-this document confirmed the rights of the mazar (religious institution) Ziya adDin-Shaikh Sygnaki for Hisarchuk spring near Sygnak (similarly to the Patent of 1597/1598 from Abu'lGhazi Abdallah-Khan-Bahadur-Sultan). In addition to the provision of Allama-yi Sygnaki's descendants with the waqf lands (waqf is an inalienable charitable endowment under Islamic law) they were also given the privileges of tarkhanship. Original version, written in the Turkic language;

5. Waqf Charter from Timur Amir to the mosque Ahmed Yasawi in Turkestan, issued in the late XIV - early XVI centuries-according to this document, at the end of the XIV century or the beginning of the XV century, Amir Timur endowed Khoja Ahmed Yasawi mausoleum with a number of irrigated lands along with irrigation canals as a waqf. Original version, written in the Persian language (as of today, the Charter is kept in the collection of documents of the Abu Rayhan Biruni Institute of Oriental Studies of the Academy of Sciences of the Republic of Uzbekistan) [20].

These sources were selected based on the following criteria: (1) the textual source was considered to be reliable through critical analysis; (2) the size of the text is enough to extract meaningful information; (3) the content of the written source enables the establishment of structural, genetic, and transformational connections between facts. Therefore, textual sources under study were arranged in accordance with the objective connections between them [21].

Edicts from Sygnak can be broken into several sections, which appear in earlier and later documents:

Invocation, where reference to God appeared;

Intitulatio, where the name and title of the person from whom the document was issued appeared;

Inscriptio, where addresses of the person to whom the document was meant for appeared;

Notificatio, where the announcement appeared;

Dispositio, where a decision that has been made is detailed;

Sanctio, where the instructions were given;

Corroboratio, an authentication of the document;

Eschatocol, which was a closing protocol.

For discourse analysis, a representative corpus of texts is required and a set of criteria should be developed. The choice of texts and criteria depends on the discourse being analyzed, on the research interest, and on a problem the scholar is intended to solve. In full-fledged investigation, on should keep in mind that textual sources arise against the background of specific events in the society.
The textual analysis of edicts shows that these documents reflected, to a certain extent, the needs of nomadic society of that time. The structure and content of edicts are something more than just a sign of progress in the clerical culture, as commonly suggested. Edicts became what they are as a result of social shifts in agrarian legal and other relations. In general terms, written sources emerged as a solution that improved the purpose-driven performance of distinct institutions.

Based on data from the edicts, nomadic tribes in the XIV century had strong institutions of tarkhanship and soyurghal, which permitted the inheritance of a tarkhan title and a piece of land on condition that the holder perform military service in the Golden Horde. Edicts indicate that feudal lands and allotments, especially winter pastures, had clear borders that were protected by their owners. This is evidenced by the following phrase from the edict by Abul-Ghazi. "The winter residence of Shah-Bekht Khan [the grandson of Abulkhair Khan] was located one oasis up the river from that of Berke Sultan [the son of Yadiger Khan]," it says [22]. This assertion shows that pastures that belonged to Shah Bekht Khan shared borders with pastures that belonged to Berke Sultan. Furthermore, both land plots had owners. Another proof of the existence of feudal land ownership is the transfer of land by inheritance, governed by the proprietorship or soyurghal grants.

Until now, scientists made judgments about the landlaw institution of soyurghal based on tarkhan grants or narrative sources of external origin. Even through the translations of soyurghal grants have long been available, their nature and specifics have not been the focus of extensive research. Future studies should close this gap because soyurghal grants represent one of the most significant and valuable groups of edicts issued during the Golden Horde period.

The research practice has shown that additional information can be found through the exploration of stylistic nuances and terminology of the formal text. One of these nuances is the use of the word "sözum" (my word) in the intitulatio, which function was to indicate the person making the proclamation [23]. All of the edicts extant had this component, which implied the highest command, decree, or order. It exists alongside the phrase "a degree with tamgha of [name of the person issuing the degree]" in corroboratio, where tamgha was a tribal sign [23]. These discourse structures were used to give patents a name until the middle of the XVI century. Since the second half of the XVI century, all privileges in corroboratio were called yarlyks or edicts (written commandants). There were also different terms used in the main test of the document to differentiate the edicts, namely mulk-nameh, berat, and maaf-nameh. 
Edicts were drawn up in full accordance with the norms of the language used to create stamps. In tarkhan grants of the Golden Horde, each section of the document is of fundamental importance. Based on the presence or absence of structural elements, a scholar can determine if the document is integral and authentic. The classification of official acts can thus be performed by comprehensively examining the levels of the discourse and its thematic hierarchy. This can help scholars investigate the evolution of feudal and other institutions of nomadic society.

The analysis of Edicts from Sygnak indicated that documents in this collection of written sources belong to the category edicts. Diplomatic analysis confirmed that the Charter from Timur Amir to the mosque Ahmed Yasawi is an endowment document waqf-nameh. The organization of this document is consistent with the official acts of the XIV-XVI centuries. The primary structure of waqf-nameh can be divided into three parts (introductory protocol, main text, and closing protocol) and $8 \mathrm{sec}-$ tions. Now, let us examine the Charter to the mosque Ahmed Yasawi. The structure of its introductory protocol (invocation, intitulatio, and inscriptio) is similar to that in the Patent of 1400-1401. The main text of the document (notificatio, sanctio, and corroboratio) comprises all of the elements integral to waqf-nameh. Finally, there is no closing protocol.

The Patents of $1400 / 1401$, of $1543 / 1544$, of $1597 / 1598$, and of 1634/1635 comprise a number of structural elements specific to edicts. Classifying structural elements (parts and sections) of edicts and differentiating the changeable and unchangeable components of the text is conducive to the reconstruction of the edict.

In modern historiology, documents analysis involves the use of methods from multiple academic disciplines that are concerned with document structure and handwriting. Research methods from related disciplines, such as linguistics and philology, can also be used in document analysis. Discourse analysis is a new technique used in linguistics, which can further be applied alongside methods from the humanities.

The results of discourse analysis in this study revealed the following. The discourse repertoire of Edicts from Sygnak is rather unique. The use of clarification-giving headings, such as maaf-name, mulk-nameh, berat, bitik, etc. in the dispositio section of the edicts enables the classification of authentic textual sources collected under the title of Edicts from Sygnak. Classifying edicts from the cities of Sygnak, Sayram, and Turkestan, the following types of documents were distinguished. Among five edicts issued in Syr Darya between XIV and XVI centuries, one is a soyurghal grant, two waqf deeds, and other two charters of privilege to military officers. However, all documents have elements of tarkhan grants (exemption from taxes and land consolidation).

Particularly noteworthy are the key words that travel from one edict to another. They designate relevant issues and reflect both time-specific ideas and stereotypes, as well as social and economic priorities. Based on edicts, one can trace changes in agricultural production models of the nomads, as well as exogenous and endogenous issues influencing social development during the formation of statehood in the XIV-XVI centuries. Thus, official acts (edicts) reflect the result of the mutual influence of sedentary and mobile lifeways [24]. Edicts from Southern Kazakhstan are dominated by waqf deeds, which are similar to that from Timur Amir to the mosque Ahmed Yasawi and from Abu-l-Ghazi Ubaydallah-Khan-Bahadur-Sultan. It is questionable, however, whether there were waqf lands in the settled agricultural oases and cities in the southwestern Zhetysu, since there is no information about those in the written sources [24]. There are evidences on the widespread possibility of land ownership for Muslim clergy across cities in the Syr Darya basin. Those areas have long been the center of settled culture, agriculture, and trade, favored by the nomadic population of Desht-i Qipchaq. The Muslim clergy had enough economic power to influence the nomadic society, as evidenced by several waqf documents.

The nomadic traditions have influenced the content of official acts. There were many institutions, such as freedom of travel, securing of land to clans and tribes, etc. In tarkhan grants, one of the most valuable privileges was the right to free travel. Another privilege, most likely originated from the mobile lifeway, was the exemption of mobile tribes from various taxes [25]. Consequently, the rights and obligations enshrined in the edicts stemmed from the very essence of the nomadic way of life. The rulers or khans took care not only to settle the non-populated areas but also to maintain the traditional, that is, mobile system of living, and edicts are the reflection of those efforts.

The arguments behind certain speech patterns are crucial in document reconstruction. Grigoryev has recreated 6 different edicts. These documents were rather well analyzed, but the comparison of speech patterns and structural elements between the authentic main text and its Russian translation revealed interpolations, transpositions of words and phrases and other inconsistencies [5]. The proposed research procedure will allow establishing the authenticity of edicts.

Edicts from khans objectively and promptly reflect the socio-economic changes occurred in the Golden Horde and subsequent khanates throughout the history. Single facts and events can only be established based on data available in edicts, since other authentic historical 
sources do not cover many socio-economic processes of the past. In these circumstances, edicts become a truly invaluable source on medieval history.

\section{Discussion}

The results of discourse analysis are consistent with conclusions drawn about discursive regularities by Michel Foucault. Take, for example, the case of Natural History in the Classical period. "It does not use the same concepts as in the XVI century," Foucault says, explaining that "some of the older concepts, such as genus, species, and signs are used in different ways; new concepts, such as structure, emerge; and others, like that of organism are formed later" [26]. Michel Foucault was certain that the general arrangement of the statements and their successive arrangement in particular wholes altered in the seventeenth century, governing the emergence and recurrence of concepts. He says "It was the way in which one wrote down what one observed and, by means of a series of statements, recreated a perceptual process; it was the relation and interplay of subordinations between describing, articulating into distinctive features, characterizing, and classifying; it was the reciprocal position of particular observations and general principles; it was the system of dependence between what one learnt, what one saw, what one deduced, what one accepted as probable, and what one postulated" [26].

In this respect, the discourse under study not only records historical events, but it also allows us to follow the journey of nomadic nations towards statehood. By comparing the same kinds of texts issued in different times, one can look closer at many phenomena happening in medieval society and study the evolution of feudal institutions from the moment of their creation to disappearance. Gradually, as the volume of research material grows, more and more attention is drawn to the development of nomadic societies, and our knowledge of what is similar and different about sedentary and mobile peoples becomes increasingly disputable. As a result, new concept will appear.

Foucault's assertion that the foundation of the oral or written discourse, the living speech, is "the way in which the modes of approximation and development of the statements are linked to the modes of criticism, commentary, and interpretation of previously formulated statements, etc. It is this group of relations that constitutes a system of conceptual formation" and allows considering the text not only as object of written culture, but also as concept carrying within itself a piece of historical memory [26]. This methodological approach significantly expands the ways of data extraction from oral and written sources.

Applying the discourse method according to Sylvia Bendel Larcher [14], it was found that alterations to the textual source over time can be seen not only in its external appearance, but also in its content. This is due the evolution of both official documents and historical methodology.

Discourse analysis is a set of analytical methods of analyzing texts generated in various socio-political, cultural, historical contexts $[27,28]$. One of the most promising areas in historical science today is the functionality of nomadic society, as a common social system in the medieval period. From this perspective, edicts with their insights into the industries of nomadic civilizations catch interest. These sources provide significant information about the ethnopolitical history, economy, and spiritual culture of nomadic society. The specificity of edicts is that they were the major tool in resolving socio-economic and land issues among sedentary and mobile population of the Golden Horde in the XIV-XVI centuries.

The Kozybayev's approach to understanding the past of nomadic society is based on the civilizational analysis of historical sources. In Kozybayev's opinion, oral sources should be widely used in the study of Turkic peoples with common roots and a common history, such as Kazakhs, Kyrgyz, Uighurs, and Uzbeks. According to him, each of them have the right to consider Mirza Muhammad Dulati to be a native historian because "he passed down a first-class source of information about the last 200 years of political, cultural, and socio-economic development of several Turkic peoples that occupied a vast region, Mogolistan" [29].

Karibaev et al. [30] contributed to historical knowledge through the exploration of consequences of socio-political transformation of the Golden Horde. The authors focused on investigating the interaction between political institutions and settled population based the latest theoretical and conceptual approaches of historical science to the study of political history. The authors shed light on the methods and principles of research concerning the life and behavior of nomadic peoples. At the same time, the extrapolation of previous historical experience is crucial for adequately determining the place of nomadic civilization in the world history [30].

At the same time, it became possible to highlight the historical and cultural significance of edicts as one of the most important components of the cultural life of the Turkic-speaking peoples. The structural analysis of edicts proves that edicts have their origins in traditions of the Turkic-speaking peoples. This study agrees with Usmanov's opinion that "the culture of writing that gave rise to legal tradition resulted from the symbiosis of several cultures, where the absorbers were Turkic-speaking peoples, such as Uyghurs in Central Asia, Kipchaks in Eastern Europe, and sedentary population of Bulgar and Khorezm" [31]. The official acts, which originated locally 
under the influence of Kipchak's written and cultural traditions, underwent a number of changes and came to their complete physical appearance over time.

\section{Conclusion}

In modern historiology, documents analysis involves the use of methods from multiple academic disciplines that are concerned with document structure and handwriting. Research methods from related disciplines, such as linguistics and philology, can also be used in document analysis. Discourse analysis is a new technique used in linguistics, which can further be applied alongside methods from the humanities.

Based on the discourse investigation in this study, the following conclusions were drawn. First, the discourse repertoire of Edicts from Sygnak is rather unique, as evidenced by comparative analysis of patents from the cities of Sygnak, Sayram and Turkestan located in the Syr Darya basin. The amount of historical materials involved in this study determined the reliability of research results. Second, edicts in this study reflect the result of the mutual influence of sedentary and mobile lifeways. The structural analysis of Edicts from Sygnak indicated that documents in this collection of written sources belong to the category edicts. The introductory protocol (invocation and intitulatio) was found to be a common element among the examined edicts, and was drawn as introductory protocols in other documents of the Golden Horde. The Patent from Abu'l-Ghazi Abdallah-Khan-BahadurSultan, for example, originally written in Persian, has a two-line introduction, which was common in edicts from great khans. The results of the structural analysis indicate the simultaneous use of words "sözum" (my word) in intitulatio and "nishan" in corroboratio. The earlier literature states that "my word" could be used in either grants or bitiks [32]. Third, the arguments behind certain speech patterns used in the examined edicts emerged under the influence of Turkic traditions.

\section{Acknowledgements \\ The framework of the grant project of the Committee of science of Ministry of Education and Science of the Republic of Kazakhstan Identification (heuristics) and classification of Khan's decrees and charters of Golden Horde and post- Golden Horde States (grant № APO8956286) hold the International scientific and practical conference Problems of studying the history of the Golden Horde: the identification and interpretation of historical sources.}

\section{Authors' contributions}

All authors contributed to the study conception and design. Material preparation, data collection and analysis were performed by Al, AT, NA and AP. The first draft of the manuscript was written by ZK and TS. All authors read and approved the final manuscript.

Funding

Not applicable.

Availability of data and materials

Data will be available on request.

\section{Declarations}

Competing interests

The authors declare that they have no competing interests.

\section{Author details}

'Department of History of Kazakhstan and Socio-Humanitarian Disciplines, M. Kozybaev North Kazakhstan University, Pushkin Street, 86, Petropavlovsk 1500000, Kazakhstan. ${ }^{2}$ Department of History of Kazakhstan, L. Gumilyov, Eurasian National University, Pushkin Street, 11, Nur-Sultan 010000, Kazakhstan.

Received: 16 April 2021 Accepted: 14 July 2021

Published online: 26 July 2021

References

1. Ibatov A. Khan's Decree Epoch Law. 2017;2:33-8.

2. Kurat AN. Golden army in the archive of Topkapı Palace Museum: Yarim and plants belonging to Kirim and Turkestan khans (Vol. 1). İstanbul: Bürhaneddin Matbaası; 1940 (in Turkish).

3. Özyetgin AM. Language and style analysis of the sheds and fragments of the Golden Army, Crimea and Kazan fields: Review, text, translation, notes, index, facsimile (Vol. 658). Ankara: Ataturk Kultur DIL Ve Tarih Yuks; 1996 (in Turkish).

4. Aksanov A. The Kazan Khanate. In: The history of the Tatars since ancient times. In seven volumes. Volume 4. Tatar states (15-18th centuries). Kazan: Sh. Marjani Institute of History, English translation; 2017. p. 146-50.

5. Grigoryev AP. Collection of Khan's edicts to Russian metropolitans. St. Petersburg: St. Petersburg State University Publishing House; 2004.

6. Pochekaev R. Pretended suzerainty: Moscow Tsars and Kazakh Khans (According to Russian-Language diplomatic documents of the end of 16th - beginning of 18th centuries). Istoriya. 2019;10(1):75.

7. Muminov AK, Kumekov BY, Sultonov UA, Shukhovtsov VK, Kenzhetayev DT, Kabylova AS, et al. A historical documents of the Mausoleum of Khoja Ahmad Yasawi. Astana: Master PO ZHSHS; 2017.

8. White H. Metahistory: The historical imagination in nineteenth-century Europe. Baltimor: Johns Hopkins University Press; 2002.

9. Tikhonov VV. Interdisciplinary approach in historiographical research: Modern Russian experience. In: Walls and bridges. Interdisciplinary approaches in historical research. Moscow: Publisher Coincidence; 2012. p. 251-8.

10. Foucault M. The archeology of knowledge (trans. AMS Smith). London: Tavistock; 1972.

11. Dessons G. Émile Benveniste, the invention of speech. In: Conference in University of Lausanne, Faculty of Letters. Lausanne: University of Lausanne; 2006. (in French).

12. Jørgensen MW, Phillips L. Discourse analysis as theory and method. London: Sage; 2002.

13. Cox RW. Civilizations: Encounters and transformations. Stud Political Econ. 1995:47(1):7-31.

14. Larcher SB. Linguistic discourse analysis: A textbook and workbook. Tübingen: Fool Francke Attempto Verlag; 2015. (in German).

15. Levin J. Nomad-state relationships in international relations: Before and after borders. New York: Springer International Publishing; 2020.

16. Golden VI, Khanate H. In: The encyclopedia of empire. New York: Wiley Blackwell; 2016. p. 1-10.

17. Favereau M. The Golden Horde and the Islamisation of the Eurasian Steppes. France: Presses Universitaires de Provence; 2018.

18. Hautala R. Latin sources on competing Catholic and Muslim Proselytizing activity among the Golden Horde's Nomads in the first quarter of the 14th century. In: Golden PB, Kovalev RK, Martinez AP, Skaff J, Zimonyi A, editors. Archivum Eurasiae Medii Aevi. Wiesbaden: Harrassowitz Verlag; 2016. p. 57-70.

19. Spitzmuller J, Warnke IH. Discourse linguistics: An introduction to theories and methods of transtextual language analysis. Berlin-Boston: DeGruyter; 2015 (in German).

20. Kumekov BY, Nastich VN, Shukhovtsev VK. Written documents from Southern Kazakhstan. Bull Kazakh SSR Acad Sci. 1977:8:70-3. 
21. Van Dijk T. Introduction: Discourse and domination. In: Discourse and power. New York: Palgrave Macmillan; 2008. p. 1-26.

22. Osinsky P. The rise and fall of the nomad-dominated empires of Eurasia. Sociol Inq. 2020, in press.

23. Khazanov AM. Steppe Nomads in the Eurasian trade. Chungara: Revista de Antropología Chilena 2019;51(1):85-93.

24. Rouse LM. Silent partners: Archaeological insights on mobility, interaction and civilization in Central Asia's past. Cent Asian Surv. 2020;39(3):398-419.

25. Hautala R. Comparing the Islamisation of the Jochid and Hülegüid Uluses: Muslim and Christian Perspectives. Revue des Mondes Musulmans et de la Méditerranée. 2018;143:1-7.

26. Eribon D. Michel Foucault, 1926-1984. Paris: Flammarion; 2011.

27. Krasina MN. Discourse, discourse analysis and methods of their application in interdisciplinary projects. Vestnik of Tver State University, Philology Series. 2018;2:159-65.

28. Ryazantseva MV, Mikhaylova N, Sokolovskiy KG, Kolomoets EN, Zatsarinnaya El. Influence of ethnic origin, gender and religion on employment and labor relations. Opción Rev Ciencias Hum Social. 2020;91:11-24.
29. Kuldibayev YG. Manash Kozybayev: Life path and scientific heritage (1985-2002). Almaty: Yeltanym Publishing House; 2018.

30. Karibaev B, Maidanali Z, Bizhanova M, Koshymova A, Noyanov Y. New methodological approaches to the study of political history of the Golden Horde in the 13th-16th centuries. Codrul Cosm. 2019;25(1):7-30.

31. Sitdikov AG, Bazarov BA, Gombozhapov AD, Nolev EV, Krasilnikov PV. 4th International Congress of the Medieval Archaeology of Eurasian Steppes. Volga River Reg Archaeol. 2020;1(31):217-26.

32. Balland D, Barfield TJ, Haider M, Frank AG. Comments on Andre Gunder Frank's "The centrality of Central Asia." Bull Concern Asian Sch. 1992;24(2):75-82.

\section{Publisher's Note}

Springer Nature remains neutral with regard to jurisdictional claims in published maps and institutional affiliations.

\section{Submit your manuscript to a SpringerOpen ${ }^{\odot}$ journal and benefit from:}

- Convenient online submission

- Rigorous peer review

- Open access: articles freely available online

- High visibility within the field

- Retaining the copyright to your article

Submit your next manuscript at springeropen.com 